\title{
PENINGKATAN HASIL BELAJAR DENGAN PENDEKATAN SAINTIFIK MENGUNAKAN BLACKBERRY MESSENGER DAN METODE JIGSAW
}

\author{
Jaenur \\ SMK Negeri 2 Purwodadi, \\ masjaen@yahoo.com
}

\begin{abstract}
This classroom action research is aimed at improving student learning outcomes using a scientific approach with the blackberry messengers and the jigsaw method. The application of scientific approaches, media BBM and methods Jigsaw is one of the innovative learning implementation to improve student learning outcomes. Based on the results of the first cycle of the classroom action research showed that: the average attitude score assesment is 76.9, the percentage of mastery of learning outcomes is $61 \%$. The average score assessment skills (psychomotor), project, and portfolio is 77.9, and the percentage of mastery of learning outcomes is $69 \%$. The average of cognitive score (cognitive) on the written test or assignment is 78.0, and the percentage of mastery of learning outcomes is $69 \%$. In the second cycle showed an increase, the average attitude score assesment (attitude) of XI TIPTL 2 is 81.4 , the percentage of mastery of learning outcomes is $89 \%$. The average score assessment skills (psychomotor), project, and portfolio is 82 , and the percentage of mastery of learning outcomes is $97 \%$. The average of cognitive score (cognitive) on the written test or assignment is 84.2, and the percentage of mastery of learning outcomes is $97 \%$.
\end{abstract}

Keywords: Learning outcomes, Scientific Approach, BBM, Jigsaw

\begin{abstract}
Abstrak: Penelitian tindakan kelas ini bertujuan meningkatkan hasil belajar siswa dengan pendekatan saintifik menggunakan Blackberry Messergers (BBM) dan metode Jigsaw. Penerapan pendekatan saintifik, media BBM dan metode Jigsaw merupakan bentuk pelaksanaan pembelajaran inovatif, diharapkan meningkatkan hasil belajar siswa. Berdasarkan hasil penelitian siklus I menunjukkan: rata-rata skor penilaian sikap (attitude) diperoleh peserta didik 76.9, persentase ketuntasan hasil belajar $61 \%$. Rata-rata skor penilaian keterampilan pada praktik, project, dan portofolio sebesar 77.9, dan persentase ketuntasan hasil belajar 69\%. Rata-rata skor penilaian pengetahuan tes tertulis maupun tugas 78.0 , persentase ketuntasan hasil belajar $69 \%$. Pada siklus II menunjukkan peningkatan yaitu: rata-rata skor penilaian sikap 81.4, persentase ketuntasan hasil belajar $89 \%$. Rata-rata skor penilaian keterampilan pada praktik, project, dan portofolio 82, persentase ketuntasan hasil belajar $97 \%$. Ratarata skor penilaian pengetahuan tes tertulis maupun tugas 84.2 , persentase ketuntasan hasil belajar $97 \%$.
\end{abstract}

Kata Kunci: Hasil Belajar, Pendekatan Saintifik, BBM, Jigsaw

\section{Pendahuluan}

Pendekatan saintifik menggunakan $B B M$ dan metode Jigsaw dianggap sebagai titian emas bagi peserta didik agar berkembang dan mengembangkan aspek pengetahuan, keterampilan dan sikap, sesuai dengan 
situasi dan kondisinya. Peserta didik adalah subjek yang memiliki kemampuan aktif mencari, mengolah, mengkonstruksi, dan menggunakan pengetahuan. Pembelajaran harus dirancang dan dilaksanakan dengan memberikan kesempatan kepada peserta didik untuk mengkonstruksi pengetahuan dalam proses pembelajaran.

Kenyataan di SMK Negeri 2 Purwodadi ada sebagian peserta didik mengalami kesulitan mengikuti materi pembelajaran, termasuk pada mata pelajaran Instalasi Motor Listrik (IML). Hal ini tampak saat menyelesaikan tugas job sheet memasang rangkaian motor listrik yang bekerja secara Direct On Line (DOL) sebagian peserta didik mendapatkan nilai yang belum mencapai Kriteria Ketuntasan minimal (KKM).

Kurikulum 2013 menganut pandangan dasar bahwa pengetahuan tidak dapat dipindahkan begitu saja dari guru ke peserta didik. Selama proses pembelajaran peserta didik didorong menemukan sendiri dan mentransformasikan informasi, mengecek informasi dengan yang sudah ada dalam ingatannya, dan melakukan pengembangan menjadi informasi atau kemampuan yang sesuai dengan lingkungan.

Penerapan pendekatan saintifik dengan menggunakan Blackberry Messenger (BBM) dan metode Jigsaw, diharapkan dapat mengatasi kesulitan yang dihadapi peserta didik selama mengikuti pembelajaran mata pelajaran IML, dengan bantuan guru dan teman melalui media belajar menggunakan $B B M$ sebagai bekal persiapan belajar yang dilaksanakan sebelum pembelajaran di sekolah. Blackberry Messenger merupakan media sosial yang popular, dan memiliki nilai efektifitas tinggi untuk menyampaikan pesan. Sehingga media BBM dapat digunakan sebagai sarana belajar. Untuk memperkuat dan mengoptimalkan potensi peserta didik dalam belajar, maka di sekolah guru menggunakan metode pembelajaran jigsaw.

Belajar pada hakekatnya merupakan kegiatan mental yang tidak dapat dilihat
(Wina Sanjaya, 2008). Artinya, proses perubahan yang terjadi dalam diri peserta didik tidak dapat disaksikan secara langsung. Belajar merupakan tindakan dan perilaku peserta didik untuk memperoleh perubahan mental (Dimyati, 2013). Belajar merupakan proses memperoleh informasi baru dengan menerapkan konsep-konsep yang relevan dengan struktur kognitif, psikomotorik dan afektif seseorang.

Hasil belajar merupakan salah satu bentuk penilaian dalam pelaksanaan pembelajaran. Dengan melaksanakan kegiatan pembelajaran diharapkan siswa dapat mengalami perubahan perilaku dari tidak dapat menjadi dapat, dari tidak terampil menjadi terampil, dan dari berkarakter tidak baik menjadi berkarakter baik. Sistem penilaian hasil belajar pada pelaksanaan pembelajaran kurikulum 2013 meliputi tiga aspek yaitu: aspek pengetahuan, keterampilan dan sikap.

Menurut Dimyati (2013), penilaian aspek pengetahuan adalah kemampuan peserta didik untuk menyalurkan dan mengarahkan aktifitas kognitifnya menggunakan konsep dan kaidah yang dimiliki untuk memecahkan masalah.

Penggolongan aspek kognitif menurut Bloom dalam Arifin (2014) ada enam tingkatan, yaitu: (a) pengetahuan, (b) pemahaman, (c) penerapan, (d) analisis, (e) sintesis, dan (f) evaluasi.

Menurut Suharsimi Arikunto (1991) penilaian aspek psikomotorik meliputi: a) gerakan tubuh yang mencolok, b) kecepatan gerak yang dikoordinasikan, c) perangkat komunikasi non verbal, d) kemampuan berbicara. Penilaian aspek psikomotorik menurut Arifin (2013) adalah jenjang penilaian kemampuan peserta didik yang berhubungan dengan gerakan tubuh dan bagian-bagiannya, mulai dari gerakan sederhana sampai dengan gerakan komplek. Dalam penelitian ini penilaian aspek psikomotorik diarahkan pada kemampuan peserta didik dalam melaksanakan praktik sebagai upaya mengoptimalkan potensinya 
dalam mewujudkan materi secara fakta, konsep, dan prinsip dalam kehidupan seharihari.

Menurut Arifin (2013), penilaian aspek afektif (sikap) adalah internalisasi sikap yang menunjukan ke arah batiniah dan terjadi bila peserta didik menjadi sadar tentang nilai yang diterima, kemudian mengambil sikap sehingga menjadi bagian dari dirinya dalam bentuk nilai dan menentukan tingkah laku. Penggolongan penilaian afektif ini meliputi menerima, merespons, menilai dan mengorganisasi.

Data hasil belajar diperlukan guru untuk mengetahui ketuntasan belajar siswa. Langkah guru untuk mengetahui hasil belajar adalah melakukan evaluasi pembelajaran. Evaluasi pembelajaran merupakan proses menentukan nilai belajar siswa melalui kegiatan penilaian dan atau pengukuran hasil belajar. Hasil Belajar bertujuan mengetahui tingkat keberhasilan yang dicapai siswa setelah mengikuti pembelajaran. Tingkat keberhasilan siswa dalam pembelajaan ditandai dengan skor, angka, kata atau huruf sebagai bentuk penghargaan. Apabila tujuan utama kegiatan evaluasi hasil belajar sudah terealisasi, maka hasilnya difungsikan dan ditujukan untuk diagnosis dan pengembangan, untuk seleksi, untuk kenaikan kelas dan untuk penempatan.

Kegiatan pada proses pembelajaran menggunakan pendekatan saintifik terdiri atas lima pengalaman belajar pokok yaitu: (a) mengamati, (b) menanya, (c) mengumpulkan informasi, (d) mengasosiasi, dan mengkomunikasikan.

Langkah-langkah pembelajaran dengan pendekatan saintifik adalah: (1) guru menyampaikan materi fakta yaitu materi konkrit yang ada di lingkungan sesuai dengan pokok bahasan dalam silabus dan RPP, (2) materi konsep yaitu konsep yang menjelaskan proses terbangunnya materi fakta, (3) materi prinsip yaitu materi yang dibutuhkan keberadaannya, (4) prosedur yaitu merumuskan langkah kerja yang dilakukan untuk memasang komponen yang dibutuhkan supaya materi konsep terbukti sesuai dengan materi fakta, (5) melaksanakan praktik berdasarkan prosedur atau langkah kerja yang telah dirumuskan, (6) membuat kesimpulan hasil praktik yang telah dilakukan, untuk menguji apakah materi fakta terbukti atau tidak.

Dalam penelitian ini penggunaan Blackberry Messenger hanya diaplikasikan dalam kontek belajar. Proses pembelajaran melalui Blackberry Messenger (BBM) group XI L2 Joos peserta didik dalam belajar merasakan bahwa pembelajaran yang sangat nyaman dan menyenangkan. Peserta didik dapat mengoptimalkan potensinya secara maksimal tanpa diiringi rasa takut, malu dan perasaan cemas lainnya jika informasi yang sampaikan belum sesuai dengan materi yang sebenarnya. Di samping itu peserta didik termotivasi untuk belajar sebagai langkah persiapan dalam proses pembelajaran. Metode pembelajaran dengan menggunakan media $B B M$ ini memiliki kelebihan antara lain: (1) pengiriman pesan dapat berlangsung secara cepat dan mudah, (2) proses komunikasi dalam pembelajaran peserta didik dapat mengaktualisasikan potensi yang dimiliki secara nyaman dan menyenangkan, (3) proses pengiriman informasi atau pesan dapat berlangsung secara berkelompok atau hanya kontak-kontak tertentu saja, (4) jika jejaring internet dan peralatan sudah tersedia penyampaian informasi relatif murah, (5) sasaran komunikasi atau penyampaian informasi dapat teridentifikasi dengan jelas dan mudah, sehingga peserta didik merasa termotivasi dan mau berperan aktif.

Salah satu faktor yang mempengaruhi siswadalammenguasaimateripelajaran adalah pemilihan metode pembelajaran. Metode pembelajaran jigsaw dapat membangun suasana kelas sebagai komunitas belajar aktif yang menghargai semua kemampuan siswa. Dalam proses pembelajaran siswa dibentuk kelompok-kelompok kecil yang tingkat kemampuannya berbeda, setiap siswa anggota kelompok harus saling bekerja sama dan saling membantu untuk memahami materi 
pelajaran. Dalam pembelajaran, belajar dikatakan belum selesai jika salah satu teman dalam kelompok belum menguasai materi pelajaran yang dilakukan (Wina Sanjaya, 2014). Pelaksanaan metode pembelajaran Jigsaw adalah cara pembelajaran dimana peserta didik ditempatkan dalam kelompok untuk mempelajari standar kompetensi atau kompetensi dasar (SK atau KD) tertentu. Kelebihan metode pembelajaran metode jigsaw adalah: (1) memacu siswa berfikir kritis, (2) memacu siswa untuk membuat kata-kata yang tepat agar dapat menjelaskan kepada teman lain. Hal ini akan memacu atau memotivasi siswa untuk mengembangkan kemampuan verbal dan sosialnya, (3) diskusi yang terjadi tidak di dominasi oleh siswasiswa tertentu tapi semua siswa dituntut untuk menjadi aktif.

Rumusan masalah dalam penelitian tindakan kelas ini adalah sebagai berikut: (1) Apakah pendekatan pembelajaran saintifik menggunakan $B B M$ dan metode pembelajaran Jigsaw dapat meningkatkan hasil belajar siswa?, (2) Berapa besar penerapan pendekatan pembelajaran saintifik menggunakan $B B M$ dan metodepembelajaran Jigsaw dapat meningkatkan pengetahuan (kognitif), keterampilan (psikomotorik), sikap (attitude) peserta didik?

Tujuan penelitian tindakan kelas ini adalah: (1) Untuk mengetahui pendekatan pembelajaran saintifik menggunakan $B B M$ dan metode pembelajaran Jigsaw dapat meningkatkan hasil belajar siswa, (2) Untuk mengetahui penerapan pendekatan pembelajaran saintifik menggunakan $B B M$ dan metode pembelajaran Jigsaw dapat meningkatkan pengetahuan (kognitif), keterampilan (psikomotorik), sikap (attitude) peserta didik sikap (attitude) peserta didik.

\section{Metode}

Penelitian ini dilaksanakan di SMK Negeri 2 Purwodadi, yang beralamat di Jl. MH. Thamrin 50 Danyang, Kecamatan Purwodadi, Kabupaten Grobogan, Telp/ Fax (0292) 425086. Subjek penelitian ini siswa kelas XI TIPTL 2 SMK Negeri
2 Purwodadi tahun pelajaran 2014/2015. Jumlah siswa kelas XI TIPTL 2 adalah 35. Materi yang digunakan dalam penelitian ini adalah memasang komponen dan sirkit motor kontrol Non Programmable Logic Control (NON PLC).

Sumber data penelitian ini dapat diperoleh dari kegiatan dan aktivitas selama pembelajaran berlangsung, informasi dan dokumen terkait penelitian. Semua kegiatan selama pembelajaran diamati dan dicatat dalam lembar observasi. Dokumen yang bisa dijadikan sumber data antara meliputi: (1) data siswa kelas XI TIPTL 2 pada SMK Negeri 2 Purwodadi, (2) data hasil pengamatan kegiatan diskusi materi memasang komponen dan sirkit motor kontrol Non Programmable Logic Control (NON PLC), (3) data hasil evaluasi memasang komponen dan sirkit motor kontrol Non Programmable Logic Control (NON PLC), (4) data hasil pengamatan praktik memasang komponen dan sirkit motor kontrol Non Programmable Logic Control (NON PLC).

Adapun teknik pengambilan dan alat pengumpulan data dilakukan dengan cara sebagai berikut: (1) peneliti mengamati dan merekam reaksi, keterlibatan, dan aktivitas siswa selama proses pembelajaran, (2) peneliti memberikan tes tertulis sebagai alat evaluasi kepada siswa setiap akhir siklus, (3) untuk mengumpulkan data tentang aktivitas dan perilaku siswa peneliti memberikan angket penilaian sikap sebelum pelaksanaan siklus berakhir.

Analisis data dalam penelitian ini adalah analisis deskriptif komparatif, yaitu mendeskripsikan perbandingan hasil belajar yang diperolah siswa antara siklus satu dengan siklus lainnya.

Tolok ukur yang digunakan untuk mengetahui keberhasilan penelitian ini adalah: (1) dinyatakan berhasil secara individu untuk penilaian psikomorik dan kognitif, jika pada tiap siklus tindakan, siswa memperoleh nilai hasil belajar minimal 77 ( batas tuntas KKM ), (2) dinyatakan berhasil secara klasikal, jika pada tiap siklus tindakan $85 \%$ dari jumlah siswa memperoleh nilai hasil 
belajar minimal 77 ( batas tuntas KKM ), (3) dinyatakan berhasil jika ada perubahan sikap (attitude) dan keterampilan (psikomotorik) siswa dengan nilai minimal baik.

\section{Hasil dan Pembahasan}

Hasil penelitian tindakan kelas ini meliputi tindakan siklus I dan Siklus II. Data hasil penelitian berupa deskripsi proses pembelajaran meliputi, aktifitas siswa dalam proses pembelajaran berlangsung, penilaian pengetahuan, keterampilan, dan sikap sebagai hasil belajar siswa. Adapun hasil belajar siswa pada siklus I dapat dilihat grafik 1 .

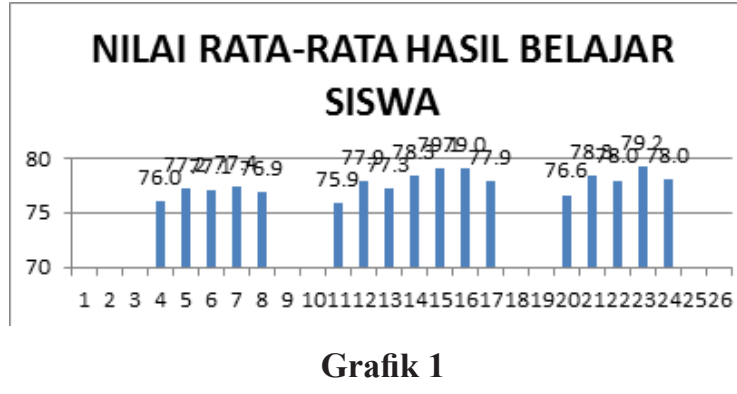

Nilai Rata-Rata Hasil Belajar Siswa Kelas XI TITL 2 Sesudah Dilakukan Tindakan Siklus I

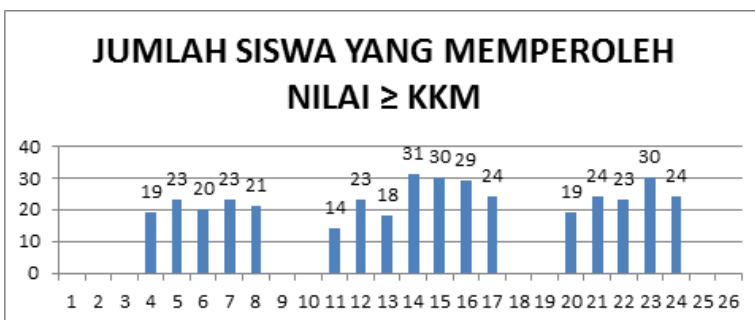

Grafik 2

Jumlah Siswa yang Memperoleh Nilai $\geq$ KKM Kelas XI TITL 2 sesudah Dilakukan Tindakan Siklus I

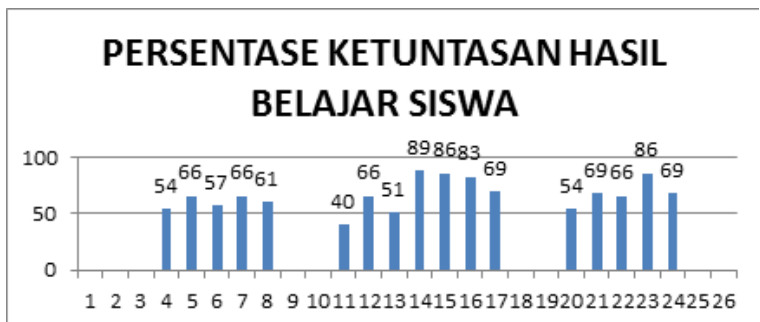

Grafik 3

Persentase Ketuntasan Hasil Belajar Kelas XI TITL 2 sesudah Dilakukan Tindakan Siklus I
Keterangan:

4: rata-rata nilai sikap berdasarkan observasi guru siklus I pertemuan 1

5: rata-rata nilai sikap berdasarkan penilaian antar teman siklus I pertemuan 1.

6: rata-rata nilai sikap berdasarkan observasi guru siklus I pertemuan 2

7: rata-rata nilai sikap berdasarkan penilaian antar teman siklus I pertemuan 2.

8: rata-rata nilai sikap berdasarkan siklus I pertemuan ke-1 dan ke-2.

11: rata-rata nilai keterampilan praktik siklus I pertemuan 1

12: rata-rata nilai keterampilan projec siklus I pertemuan 1

13: rata-rata nilai keterampilan portofolio siklus I pertemuan 1

14: rata-rata nilai keterampilan praktik siklus I pertemuan 2

15: rata-rata nilai keterampilan projec siklus I pertemuan 2

16: rata-rata nilai keterampilan portofolio siklus I pertemuan 2

17: rata-rata nilai keterampilan siklus I pertemuan ke-1 dan ke-2

20: rata-rata nilai pengetahuan berdasarkan tes tertulis siklus I pertemuan 1

21: rata-rata nilai pengetahuan berdasarkan tugas siklus I pertemuan 1.

22: rata-rata nilai pengetahuan berdasarkan tes tertulis siklus I pertemuan 2

23: rata-rata nilai pengetahuan berdasarkan tugas siklus I pertemuan 2.

24: rata-rata nilai pengetahuan siklus I pertemuan ke-1 dan ke-2

Dari pencapaian hasil belajar baik pada nilai sikap, keterampilan dan pengetahuan hasil tindakan pada siklus I pertemuan 1 dan 2, yang nampak seperti pada grafik di atas, dapat dikatakan bahwa, masih rendah. Adapun hasil belajar siswa pada siklus II dapat dilihat dalam grafik berikut ini. 


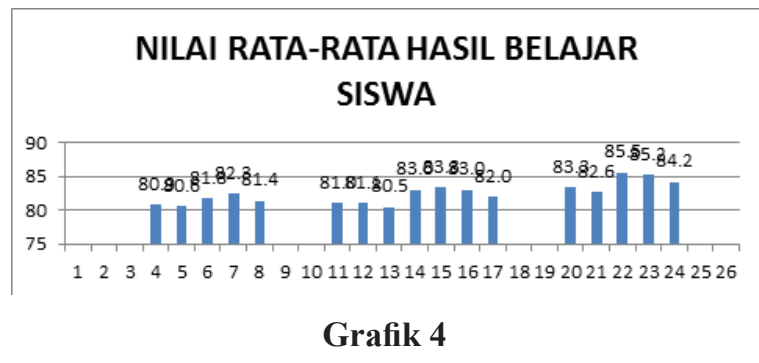

Nilai Rata-Rata Hasil Belajar Siswa Kelas XI TITL 2 sesudah Dilakukan Tindakan Siklus II

JUMLAH SISWA YANG MEMPEROLEH NILAI $\geq$ KKM

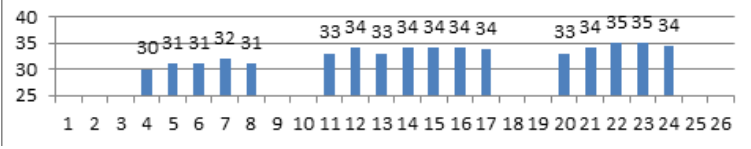

Grafik 5

Jumlah Siswa yang Memperoleh Nilai $\geq$ KKM

Kelas XI TITL 2 sesudah Dilakukan Tindakan

Siklus II

PERSENTASE KETUNTASAN HASIL BELAJAR SISWA

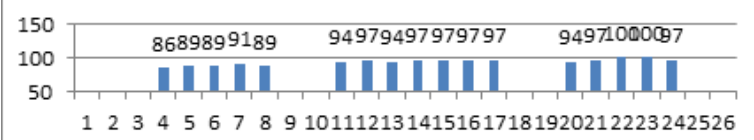

Grafik 6

Persentase Ketuntasan Hasil Belajar Kelas XI

TITL 2 sesudah Dilakukan Tindakan Siklus I

Keterangan:

4: rata-rata nilai sikap berdasarkan observasi guru siklus II pertemuan 1

5: rata-rata nilai sikap berdasarkan penilaian antar teman siklus II pertemuan 1 .

6: rata-rata nilai sikap berdasarkan observasi guru siklus II pertemuan 2

7: rata-rata nilai sikap berdasarkan penilaian antar teman siklus II pertemuan 2 .

8: rata-rata nilai sikap berdasarkan siklus II pertemuan ke-1 dan ke-2.

11: rata-rata nilai keterampilan praktik siklus II pertemuan 1

12: rata-rata nilai keterampilan projec siklus II pertemuan 1

13: rata-rata nilai keterampilan portofolio siklus II pertemuan 1
14: rata-rata nilai keterampilan praktik siklus II pertemuan 2

15: rata-rata nilai keterampilan projec siklus II pertemuan 2

16: rata-rata nilai keterampilan portofolio siklus II pertemuan 2

17: rata-rata nilai keterampilan siklus II pertemuan ke-1 dan ke-2

20: rata-rata nilai pengetahuan berdasarkan tes tertulis siklus II pertemuan 1

21: rata-rata nilai pengetahuan berdasarkan tugas siklus II pertemuan 1.

22: rata-rata nilai pengetahuan berdasarkan tes tertulis siklus II pertemuan 2

23: rata-rata nilai pengetahuan berdasarkan tugas siklus II pertemuan 2.

24: rata-rata nilai pengetahuan siklus II pertemuan ke-1 dan ke-2

Kegiatan inti pembelajaran menggunakan pendekatan saintifik terdiri atas lima pengalaman belajar pokok yaitu: (a) mengamati, (b) menanya, (c) mengumpulkan informasi, (d) mengasosiasi, dan (e) mengkomunikasikan. Agar benarbenar memahami dan dapat menerapkan pengetahuan, peserta didik perlu didorong untuk bekerja memecahkan masalah, menemukan segala sesuatu untuk dirinya, dan berupaya keras mewujudkan ideidenya. Langkah-langkah dalam pelaksanaan pembelajaran metode jigsaw adalah sebagai berikut: (1) kelas dibagi menjadi beberapa kelompok atau tim, (2) tiap kelompok atau tim terdiri dari 3 atau 4 siswa, (3) tiap siswa dalam tim diberi materi dan tugas yang berbeda, (4) anggota dari tim yang berbeda yang telah mempelajari materi atau tugas yang sama bertemu dalam kelompok baru untuk mendiskusikan materi mereka, (5) setelah selesai diskusi sebagai tim ahli tiap anggota kembali ke kelompok asal dan bergantian mengajar teman satu tim mereka tentang materi atau tugas yang mereka kuasai dan tiap anggota lainnya mendengarkan dengan sungguh-sungguh, (6) tiap tim ahli mempresentasikan hasil diskusi, (7) guru memberikan evaluasi, (8) penutup 
Selama pelaksanaan pembelajaran guru memantau kerja masing-masing kelompok kecil untuk mengetahui proses kegiatan berlangsung. Dalam metode ini guru tidak banyak menjelaskan materi kepada siswa. Guru hanya menyampaikan garis besar materi dalam bentuk pertanyaan yang menjadi kerangka selama diskusi bagi kelompok ahli. Disamping itu guru berperan sebagai fasilitator dan mediator dalam kegiatan belajar - mengajar yang berlangsung.

Metode Pembelajaran metode jigsaw merupakan metode pembelajaran yang dapat membangun suasana kelas sebagai komunitas belajar aktif yang menghargai semua kemampuan siswa. Pemikiran dasar dari metode ini adalah memberikan kesempatan siswa untuk berbagi pengetahuan dengan yang lain. Metode pembelajaran yang digunakan oleh guru berpengaruh terhadap kualitas proses mengajar yang dilakukannya. Oleh karena itu upaya yang harus dilakukan oleh guru adalah memilih metode pembelajaran yang tepat sesuai dengan materi dan tujuan yang akan diharapkan. Salah satu metode pembelajaran yang dapat berlangsung secara aktif, inovatif, kreatif, dan menyenangkan adalah pembelajaran metode jigsaw.
Berdasarkan hasil penelitian tindakan kelas di atas penggunaan pendekatan saintifik dengan $B B M$ dan metode Jigsaw dapat meningkatkan hasil belajar siswa baik aspek sikap (attitude), aspek keterampilan (psikomotorik), dan aspek pengetahuan (kognitif).

\section{Kesimpulan}

Berdasarkan hasil penelitian tindakan kelas ini penerapan pendekatan saintifik menggunakan Blackberry Messenger (BBM) dan metode pembelajaran jigsaw dapat meningkatkan hasil belajar siswa baik aspek sikap (attitude), aspek keterampilan (psikomotorik), dan aspek pengetahuan (kognitif), siswa kelas XI TIPTL2 SMK Negeri 2 Purwodadi.

Guru hendaknya melakukan inovasi pembelajaran secara terus-menerus dalam rangka untuk meningkatkan kompetensi pedagogik, kepribadian, sosial dan profesional agar menjadi guru yang profesional. Sekolah dan pihak dinas pendidikan hendaknya memotifasi dan memfasilitasi kegiatan penelitian untuk meningkatkan kualitas pendidikan di Indonesia.

\section{Daftar Pustaka}

Arikunto, Suharsimi. 1996. Dasar-Dasar Evaluasi Pendidikan. Jakarta : Bina Aksara.

Arifin, Zainal. 2013. Evaluasi Pembelajaran. Bandung : PT Remaja Rosdakarya.

Januari, Didik dan Murtafi'atun. 2014. Tri

k A-Z Menjadi Guru Kreatif dirindui dan dicintai murid.Yogyakarta: Indoliterasi.

Dimyati dan Mudjiono. 2013. Belajar \& Pembelajaran. Jakarta : PT Rineka Cipta.

Muhibbin Syah. 2003. Psikologi Belajar. Jakarta: PT. Raja Grafindo Persada.

Nur, Mohamad. 2001. Pengajaran Berpusat Kepada Siswa dan Pendekatan Konstruktivis dalam Pengajaran. Surabaya : UNESA-University Press.

Sanjaya, Wina. 2008. Pembelajran dalam Implementasi Kurikulum Berbasis Kompetensi. Jakarta : Kencana Prenada Media .

Sanjaya, Wina. 2014. Strategi Pembelajaran Berorientasi Standar Proses Pendidikan. Jakarta : Kencana Prenada Media .

Slavin. 1994. Educational Psychology, 4th ...

Sianipar. 1999. Perencanaan Kinerja. Republik Indonesia : Lembaga Administrasi Negara. 
Subyantoro. 2009. Penelitian Tindakan Kelas.Edisi Revisi. Semarang : Widya Karya.

Sudjana. 1991. Teori-teori Belajar untuk Pengajaran. Lembaga Penerbit : Fakultas Ekonomi Universitas Indonesia.

Suhardjono.2010. Penelitian Tindakan Kelas \& Penelitian Tindakan Sekolah. Malang : Cakrawala Indonesia dengan LP3 UM.

Sugiyono. 1999. Metode Penelitian Bisnis. Bandung : CV. Alpabeta.

Sukmadinata, Nana Syaodih. 2013. Metode Penelitan Pendidikan. Bandung : PT Remaja Rosdakarya.

Supardi. 2011. Hasil Penelitian dan Pembahasan dalam PTS. Makalah Fasilitasi Kompetensi Penelitian Tindakan Sekolah Kepala Sekolah (SMA/SMK) Propinsi Jawa Tengah.di Semarang.

Solihatin.2007.Cooperative Learning Analisis Metode Pembelajaran IPS. Jakarta: Penerbit PT Bumi Aksara. 